\title{
THESES
}

\section{MIGRAINE IN CHILDHOOD AND ADOLESCENCE: A CRITICAL STUDY OF DIAGNOSTIC CRITERIA AND INFLUENCE OF AGE ON CLINICAL FINDINGS (ABSTRACT)*. THESIS. SÃO PAULO, 1998.}

\section{JOSÉ LUIZ DIAS GHERPELLI **}

Two hundred and fifty-three children, aged $<15$ years old, comprised the study group. The study was divided in 2 phases.

Phase 1 included 193 children with migraine with and without aura (1.1 and 1.2) diagnosed according to the IHS criteria, with a mean age of $10,3 \mathrm{y}$., divided in 2 groups according to their age $(<10$ or $\geq 10$ years). We studied the relationship between age and migraine type, headache characteristics and associated symptoms that are part of the IHS definition. Results showed a statistically significant higher frequency of migraine with aura in children $\geq 10$ years old $(\mathrm{p}=0.0002)$ compared to those with $<10$ years; nonparametric statistical analysis showed a significant relation between older age and increase in migraine with aura frequency $(\mathrm{p}=0.0003)$. Pulsatile quality and unilateral pain location were also related to age, being more frequent in older children ( $\mathrm{p}=0.02$ and $\mathrm{p}=0.01$, respectively).

Phase 2 studied 176 children with headache $(1.1,1.7,2.1,2.2,4)$, excluding those with migraine with aura. The objectives were to: 1 . analyze which of the IHS definition items were responsible for the children's exclusion of the migraine (1.1) diagnosis; 2. study the concordance degree between the restrictive IHS criteria, Prensky and Vahlquist criteria, compared to an "extended" criteria used as a "gold standard", that included the non-classified children in the migraine group; 3 . study the degree of sensitivity and specificity for each of the definition items of the IHS definition and; 4. analyze alternative definitions, based on the restrictive IHS definition, which could improve the sensitivity concerning the children of the 1.7 diagnostic group. The results showed that item $\mathrm{B}$ of the definition was the most frequent cause of exclusion in the 1.7 diagnostic group, compared to items C and D (all children fulfilled item A). Prensky criteria showed the highest sensitivity, compared to the Vahlquist and IHS, although all three criteria showed sensitivity over $70 \%$. Headache characteristics and associated symptoms that showed sensitivity over $70 \%$, in decreasing order of frequency, were: pain of moderate/severe intensity, pain duration between 2 to 48 hours, isolated photophobia, isolated phonophobia and aggravation with physical activity. Headache characteristics and associated symptoms that showed specificity over $70 \%$, in decreasing order of frequency, were: nausea, vomiting, phonophobia and photophobia (all 3 with $100 \%$ ), isolated photophobia, aggravation with physical activity and isolated phonophobia. Based on 3 alternative definitions, each of them modifying one item of the IHS definition (with the exception of item A), while maintaining the others unchanged, we compared the sensitivity and specificity of these alternative definitions with the "extended" criteria. We observed that the exclusion of item B led to a $10 \%$ increase of sensitivity compared to the restrictive IHS, without losing specificity.

We concluded that item B of the IHS criteria for migraine without aura in children and adolescents could be removed. This would include a number of patients, which are presently non-classified, without increasing the number of false-positives. \section{sensitivity.}

KEY WORDS: migraine, headache, migraine diagnosis, childhood, adolescence, specificity,

\footnotetext{
* Enxaqueca na infância e adolescência: estudo da influência da idade sobre os sintomas clínicos e estudo crítico dos critérios diagnósticos (Resumo). Tese de Livre-Docência: Disciplina de Neurologia Infantil, Departamento de Neurologia, Faculdade de Medicina da Universidade de São Paulo.

** Address: Hospital I. Albert Einstein, Av. Albert Einstein 627 conj 356, 05651-901 São Paulo SP, Brasil. e-mail: jldg@mandic.com.br
} 


\section{ENDOSCOPIC THIRD VENTRICULOSTOMY IN THE TREATMENT OF NON-COMMUNI- CATING HYDROCEPHALUS (ABSTRACT)*. THESIS. RECIFE, 1997.}

\section{HILDO ROCHA CIRNE DE AZEVEDO FILHO**}

Hydrocephalus is cause of raised intracranial pressure, neurological dysfunction and eventually death. The employment of shunts to control the hydrocephalic process, in use for forty years and despite marked technical improvement, is undoubtly associated with infectious and mechanical complications.

Endoscopic third ventriculostomy is proposed, as a therapeutic alternative, to patients with noncommunicating hydrocephalus.

Seventy one patients were operated upon by the author using this technique. According to the aetiology of the non-communicating hydrocephalus the patients were divided into four groups: Group A (tumoural) $34(47.8 \%)$ patients; Group B (cerebral aqueduct stenosis) 19 (26.8\%) patients; Group C (associated with myelomeningocele) four (5.6\%) patients; and Group D (post-meningitis and post-intracranial haemorrhage) $14(19.7 \%)$ patients.

The endoscopic technique was successful on controlling the raised intracranial pressure in $50(70.4 \%)$ patients; on the other hand, the method was uneffective in $21(29.6 \%)$ patients.

The successful rates were $88.2 \%$ for patients in Group A; $78.9 \%$ for patients in Group B; $25 \%$ for patients in Group C; and 28.5\% for patients in Group D. In none of the 15 patients with age under one year, the method was successful. Ventriculo-peritoneal shunts were employed on 17 of the 21 patients who had an unfavourable response to the endoscopic treatment.

One $(1.4 \%)$ patient has died of cause directly related to the method, although three (4.2\%) patients have died of causes undirectly related to the method. CSF leak through the surgical wound was detected on nine $(12.7 \%)$ patients and raised significantly the risk of meningitis verified on four (5.6\%) patients.

The findings of ventriculomegaly reduction, the openning of the floor of the third ventricle and CSF flow through the fenestration observed on the post-operative MRI were significantly related to the effectiveness of the method.

\section{KEY WORDS: non-communicating hydrocephalus, endoscopic third ventriculostomy.}

*Terceiro ventriculostomia endoscópica no tratamento das hidrocefalias não-comunicantes (Resumo). Tese de Doutorado, Centro de Ciências da Saúde da Universidade Federal de Pernambuco (Área: Neurocirurgia). Orientador: Miguel Z. Doherty.

**Address: Rua Apipucos 317 / 601, 52071-000 Recife PE, Brasil.

\section{EPILEPSY AND WORK: THE RELATIONSHIP (ABSTRACT)*. DISSERTATION. SÃO JOSÉ DO RIO PRETO, 1997.}

MOACIR ALVESBORGES **

The present dissertation is a prospective study which evaluates 145 epileptic out patients from HB ambulatory of a medical school. A control group (CG) of 100 healthy volunteers were matched for similar age, sex and zip code area to compare the two groups. The mean age of both groups at testing were 35.32 years, with a range of 14- 65 and composed by $50 \%$ men. The results are showed below:

Statistical analysis: To detect any differences between these two groups $t$ Student, chi-squared and limits of confidence intervals $(95 \% \mathrm{Cl})$ were carried out. Significant level was $\mathrm{p} \leq 0.05$.

- general-working epileptic population (both sexes) was $67.59 \%$; similar to $76 \%$ of CG, although men working, $24.14 \%$, was lower than women, $43.45 \%$;

- paid-working epileptic population was $40 \%$; lower than the CG, $62 \%$, although men was $35.71 \%$; higher than women, $23.46 \%$;

- formal-working epileptic population was $24.14 \%$; lower than CG, 36\%; although the men was $37.93 \%$, higher than women, $22.41 \%$;

- retired epileptic population was $17.24 \%$; higher than the CG, $2 \%$; retired men, $76 \%$; higher than women, $24 \%$; 
- unemployed epileptic population was $15.17 \%$; similar to the CG, $22 \%$; similar range between men and women; that is: $54.54 \%$ and $45.46 \%$ respectively.

Epileptic crisis frequencies have not influenced the work of population as it is showed below: - paid-works population: weekly, $32.75 \%$; monthly $27.58 \%$ and yearly crisis, $39.65 \%$; - unemployed population: weekly, $37.83 \%$; monthly $29.72 \%$ and yearly crises, $33.43 \%$.

Epilepsy is not disadvantageous to general work , considering the non-paid housework service by women, although it is disadvantageous to the paid-salary work, similar to Jacoby, 1995 and Scambler \& Hopkins, 1980 findings. Epilepsy increases the number of retired population compared to the CG, as so, decreasing people unemployed rate. The seizure frequency has not influenced the number of working population, differently as observed by Jacoby et al., 1996. The number of unemployed was not affected by the crisis frequency, the same as proposed by the mentioned authors.

This study may allow professionals and public health care who have been concerning to epilepsy to make a reflection about the relation between the epileptic inherent matters and the insertion of this population in the work environment and also compare the literature findings.

\section{KEY WORDS: epilepsy, working, unemployment, retired, sex.}

*Epilepsia e sua relação com trabalho (Resumo). Dissertação de Mestrado, Faculdade de Medicina de São José do Rio Preto (Área: Medicina Interna). Orientadora: Emirene M. T. Navarro da Cruz.

**Address: Av. Faria Lima 5622, 15090-000 São José do Rio Preto SP, Brasil. FAX 0172276566.

THESES é seção de Arquivos de Neuro-Psiquiatria que divulga os resumos em inglês de teses defendidas e aprovadas. $\mathrm{O}$ assunto da tese deve estar relacionado a aspectos clínicos ou experimentais de interesse em neurologia, ciências a ela afins e psiquiatria.

Para publicação, o Autor deve encaminhar ao Editor: abstract da tese, acompanhado do título em inglês e em português; key words; disquete com a reprodução desses dados.

Adicionalmente, o Autor deve informar: a natureza da tese (Dissertação/Tese de Mestrado, Tese de Doutorado, Tese de Livre-Docência - como exemplos); nome da instituição na qual foi defendida e respectiva área de concentração; nome do Orientador, quando for o caso; endereço para correspondência. 